\title{
FUNGSI PRAGMATIK METAFORA DALAM WACANA SURAT PEMBACA BERBAHASA INDONESIA
}

\author{
Deli Nirmala \\ Fakultas Ilmu Budaya Universitas Diponegoro \\ email: deliundip@gmail.com
}

\begin{abstract}
Abstrak
Penelitian ini bertujuan mendeskripsikan fungsi pragmatik metafora dalam wacana surat pembaca berbahasa Indonesia. Pengumpulan data menggunakan teknik non participant observation dengan notetaking technique. Analisis data menggunakan teknik referensial, distribusional, refleksif introspektif, dan inferensi abduktif. Hasil pembahasan menunjukkan bahwa metafora dalam wacana surat pembaca mengandung fungsi pragmatik berupa asertif, direktif, dan ekspresif. Fungsi pragmatik yang ditemukan mengindikasikan ketidaklangsungan maksud dalam ungkapan metaforis. Ketidaklangsungan maksud menunjukkan adanya strategi kesantunan penulis surat pembaca untuk tetap menjaga hubungan baik dengan pembaca. Penulis surat pembaca memberikan keleluasaan kepada pembaca untuk setuju atau tidak setuju dengan wacana yang dikemukakan.
\end{abstract}

Kata kunci: ungkapan metaforis, fungsi pragmatik, dan strategi kesantunan

\section{PRAGMATIC FUNCTIONS OF METAPHORS IN THE DISCOURSE OF INDONESIAN LETTERS TO EDITORS}

\begin{abstract}
This study aims to describe the pragmatic functions of metaphors in the discourse of letters to the editor in Indonesian. The data were collected through non-participant observations using a note-taking technique. They were analyzed using referential, distributional, introspective, reflexive, and abducting inference techniques. The findings show that the metaphors in the discourse of letters to the editor show assertive, directive, and expressive pragmatic functions. Such functions indicate indirectness of meanings in metaphorical expressions. The indirectness of meanings shows the writers' politeness strategies to maintain good relations with the readers. The writers give freedom to the readers to agree or disagree with the proposed discourse.
\end{abstract}

Keywords: metaphorical expressions, pragmatic functions, politeness strategies

\section{PENDAHULUAN}

Wacana surat pembaca merupakan salah satu rubrik dalam surat kabar atau majalah, yang ditulis untuk menyampaikan perasaan, pendapat, pikiran, kritikan, dan gagasan yang ditujukan kepada individu atau lembaga baik pemerintah maupun swasta. Surat pembaca ditulis karena ada kekurangan, masalah, kerugian, atau penyimpangan, yang mungkin menyebabkan ketidaknyamanan, ketidakamanan, kerugian, kegelisahan, atau bahkan bahaya yang dapat membahayakan kehidupan manusia.

Sebagai manusia yang hidup di tengah-tengah masyarakat, penulis surat pembaca ketika menyaksikan atau mengalami sendiri suatu peristiwa yang mungkin dapat mengakibatkan hal yang tidak baik, ia merasa terpanggil untuk menanggapi dan menyampaikannya ke masyarakat sebagai bentuk kepeduliannya terhadap orang lain atau dunia. Keterpanggilan untuk ikut memikirkan atau 
memberikan pendapat atau gagasan, merupakan salah satu pemenuhan kebutuhan manusia yaitu: kebutuhan untuk saling mencintai antarsesama dalam menjaga keberlangsungan hidup di dunia.

Dalam menyampaikan maksudnya, penulis surat pembaca tidak jarang menggunakan ungkapan-ungkapan metaforis. Ungkapan-ungkapan itu dapat menjadi dasar dalam memformulasikan metaforametafora yang menunjukkan konseptualisasi yang secara implisit terkandung dalam ungkapan-ungkapan metaforis itu. Ungkapan metaforis mengandung daya metaforis yang dapat dikategorikan ke dalam makna lapis kedua (Kittay, 1987).

Selain memiliki makna lapis kedua, ungkapan metaforis memiliki makna lapis ketiga, yaitu fungsi pragmatik yang mengimplikasikan strategi kesantunan. Kajian ini hanya memfokuskan pada makna lapis ketiga, yaitu fungsi pragmatik dan strategi kesantunan yang terkandung dalam metafora dalam wacana surat pembaca.

Permasalahan yang diajukan dalam penelitian, yaitu (1) fungsi pragmatik apa sajakah yang digunakan penulis surat pembaca dalam menyampaikan maksudnya dan (2) strategi kesantunan apa sajakah yang tersirat dalam ungkapan metaforis yang digunakan penulis surat pembaca. Berdasarkan dua permasalahan tersebut, penelitian ini bertujuan untuk menunjukkan fungsi pragmatik ungkapan-ungkapan metaforis dalam wacana surat pembaca, dan mengungkapkan strategi kesantunan yang digunakan oleh penulis surat pembaca dalam berkomunikasi dengan pihak-pihak yang dituju.

Setiap tuturan tidak hanya digunakan untuk menyatakan sesuatu tetapi juga untuk melakukan sesuatu. Tuturan yang mengandung tindakan dinamakan tuturan performatif (Austin, 1968:6-7). Berdasarkan penjelasan itu, ungkapan metaforis dapat dikategorikan mengandung suatu tindakan apabila diletakkan dalam konteksnya. Ketika berada dalam konteksnya, suatu ungkapan metaforis tidak hanya memiliki makna literal dan makna lapis kedua atau daya metaforis, tetapi juga makna lapis ketiga, yaitu fungsi pragmatik.

Tuturan performatif berbeda dengan tuturan konstatif karena proposisinya yang berbeda. Tuturan performatif mengandung tindakan, sedangkan tuturan konstatif mengandung nilai benar atau salah apabila dihubungkan dengan kenyataan yang diacu (Austin, 1968:3). Akan tetapi, Austin (1968:67; 94) juga menyatakan bahwa sangat sulit untuk membedakan antara tuturan performatif dengan konstatif. Karena tuturan yang dihasilkan penutur atau penulis selalu sarat dengan konteks, dan ketika berada dalam konteks, tuturan cenderung mengandung tindakan. Tuturan yang sama dapat dikategorikan performatif atau konstatif. Oleh karena itu, dapat disimpulkan bahwa semua tuturan yang digunakan dalam berkomunikasi dapat dikategorikan performatif.

Metafora merupakan hasil abstraksi konsep yang terkandung dalam ungkapan metaforis. Ungkapan metaforis adalah ungkapan yang menunjukkan konseptualisasi dan mengindikasikan pemahaman atas suatu konsep dengan konsep lain. Metafora merefleksikan apa yang dipikirkan, dialami, dan apa yang dirasakan dalam kehidupan sehari-hari (Lakoff dan Johnson, 2003:3). Langacker (1987) menyatakan bahwa pikiran itu merupakan bentangan pengetahuan ensiklopedik yang kaya, dalam penggunaannya manusia mengaktifkan dengan mengaitkan hubungan antarleksikon mental yang sesuai dengan konteks terjadinya pertuturan. Fillmore mendukung pandangan itu dengan menyatakan bahwa bahasa digunakan untuk menciptakan bingkai pengalaman yang dapat mengonstruksikan konteks tertentu (Evans dan Green, 2006:11). Bingkai-bingkai pengalaman 
itu berada dalam manahnya, sehingga bingkai-bingkai pengalaman itu akan membantu memahami makna (Djawanai, 2009).

Menurut Croft dan Cruse (2004:102103) konteks dapat dibedakan menjadi konteks linguistik (linguistic context), konteks fisik (physical context), konteks sosial (social context), dan pengetahuan yang tersimpan dalam manah (stored knowledge). Konteks linguistik dapat dibedakan menjadi tiga aspek, yaitu: wacana sebelumnya, lingkungan linguistik langsung, dan jenis wacana. Yang dimaksudkan dengan wacana sebelumnya adalah apa yang telah dikatakan yang terjadi seketika sebelum suatu tuturan dihasilkan, dan lingkungan linguistik langsung adalah frase atau kalimat yang berpengaruh sangat kuat terhadap munculnya tuturan itu, sedangkan jenis wacana mengacu pada genre, register, atau medan wacana (field of discourse). Konteks fisik berupa apa saja yang dapat dilihat, dengar di lingkungan sekitarnya. Adapun konteks sosial mengacu pada jenis situasi yang menunjukkan hubungan sosial antarpartisipan, dan pengetahuan yang tersimpan (stored knowledge) mengacu pada semua tuturan yang diolah karena latar belakang pengetahuan dan pengalaman yang dapat mempengaruhi munculnya suatu tuturan.

Oleh karena itu, suatu tuturan dapat dipastikan mengandung suatu tindakan. Setiap tuturan performatif dapat diidentifikasi melalui indikator tindak ilokusi yang terdiri atas word order, stress, intonation contour, punctuation, the mood of the verb, dan performative verbs (Searle, 1977:30). Berdasarkan indikator tersebut, tindak tutur dapat dikelompokkan menurut titik ilokusinya yang terdiri atas asertif (assertives), komisif (commissives), ekspresif (expressives), direktif (directives), dan deklarasi (declarations). Keberadaan indikator-indikator itu menjadi penentu kelangsungan dan ketidaklangsungan maksud yang terkandung dalam suatu tuturan. Ketiadaan indikator dalam suatu tuturan dapat menjadi penentu bahwa maksud yang terkandung dalam tuturan itu menjadi tidak langsung, karena ungkapan metaforis dapat diinterpretasikan memiliki maksud penutur yang melebihi makna yang terkandung didalamnya, yang menjadikan ungkapan metaforis dikategorikan mengandung tindak tutur tidak langsung (Stern, 2000).

Fungsi pragmatik yang direpresentasikan melalui ungkapan metaforis yang digunakan penulis surat pembaca dalam menyampaikan maksudnya ditujukan kepada pembaca yang bertindak sebagai individu atau lembaga. Tuturan performatif dapat dibedakan menjadi eksplisit dan implisit (Austin, 1968:69). Tuturan performatif eksplisit dapat dikenali melalui verba yang ada dalam tuturan itu, sedangkan tuturan performatif implisit tidak mengandung verba performatif, namun dapat dikenali dari konteksnya. Ada kaidah-kaidah yang dapat digunakan untuk menentukan fungsi suatu tuturan yang dikemukakan Searle (1977:67) yang didukung Vanderveken (1990), meliputi: propositional content, preparatory, sincerity, dan essential conditions. Dari keempat kaidah itu, propositional content mendominasi dalam menentukan fungsi pragmatik yang dihubungkan dengan konteks ungkapan metaforis yang digunakan karena yang dianalisis adalah tuturan dalam wacana tulis yang kehadiran dan reaksi interlokutor tidak langsung dapat diamati.

Reaksi atau respons mitra tutur atau interlokutor bisa menjadi penentu dalam menentukan maksud tuturan (Sudaryanto (1993). Akan tetapi, berhubung data yang dianalisis adalah ungkapan-ungkapan metaforis yang ada dalam wacana surat pembaca, reaksi atau respons pembaca tidak bisa dijadikan sebagai penentu karena tidak dapat diperoleh secara langsung. Oleh karena itu, analisis yang dilakukan didasarkan pada konteks linguistik, yaitu unit linguistik yang mengitari ungkapan 
metaforis, dan konteks nonlinguistik yang berupa kesamaan pengalaman yang dialami oleh penulis dan pembaca surat pembaca, hubungan antara lokutor dan interlokutor. Kesamaan pengalaman atau pengetahuan dapat menjadi konteks yang biasanya dinamakan common knowledge oleh Lewis dalam Sperber dan Wilson (1995) atau mutual knowledge oleh Schiffer dalam Sperber dan Wilson (1995). Konteks itu juga menjadi dasar dalam menginterpretasikan fungsi pragmatik metafora dalam wacana surat pembaca.

\section{METODE}

Penelitian ini merupakan penelitian deskriptif karena penelitian ini bertujuan untuk menggambarkan fakta secara objektif dan sistematis berkenaan dengan perilaku berbahasa dalam wacana tulis. Dalam penelitian ini secara khusus dijelaskan ungkapan metaforis digunakan penulis surat pembaca dalam berkomunikasi dengan pihak yang menjadi sasaran tuturnya. Berdasarkan cara analisisnya, penelitian ini dikategorikan penelitian kualitatif dengan menggunakan referential identity method (metode padan referensial), refleksif introspektif, distributional method dan abductive inferential (inferensi abduktif) ((Sudaryanto, 1993; Krippendorff, 2004). Metode padan referensial digunakan untuk menunjukkan referen yang diacu oleh ungkapan metaforis yang dijadikan dasar dalam memformulasikan metafora. Metode abductive inferential digunakan untuk menunjukkan konseptualisasi yang terkandung dalam metafora yang diformulasikan dan fungsi pragmatik serta strategi kesantunan yang tersirat dalam ungkapan metaforis. Adapun metode refleksif introspektif digunakan untuk menunjukkan referen ungkapan metaforis untuk mendukung metode padan refensial. Metode distribusional digunakan untuk menunjukkan kejadian ungkapan metaforis, menunjukkan fungsi pragmatik, dan strategi kesantunan.
Data dalam penelitian ini adalah ungkapan yang menunjukkan konseptualisasi yang mengindikasikan adanya sistem konsep yang terdiri atas konsep ranah target dan konsep ranah sumber. Sampel dipilih dan dipilah sesuai dengan fungsi pragmatik serta strategi kesantunan yang dikandungnya. Fungsi pragmatik diinferensikan berdasarkan konteks penggunaan ungkapan metaforis. Konteks dalam penelitian ini adalah konteks linguistik maupun nonlinguistik. Konteks linguistik mengacu pada tuturan yang berada sebelum dan sesudahnya ungkapan metaforis, sedangkan konteks nonlinguistik mengacu pada peran penutur, kedudukan penutur, serta hubungan antara penutur dan mitra tutur.

\section{HASIL DAN PEMBAHASAN}

Berdasarkan titik ilokusinya, ungkapan metaforis dapat dikategorikan memiliki tiga fungsi pragmatik, yaitu asertif, direktif, dan ekspresif. Pertama, fungsi asertif metafora dalam wacana surat pembaca dalam surat kabar harian berbahasa Indonesia memiliki subfungsi melaporkan, menginformasikan, menyanjung, mengejek, mencela, mengingatkan, mengecam, menunjukkan ironi, menyalahkan, menunjukkan fakta, mengritik, memberikan solusi, menunjukkan efek, menginferensikan, menjelaskan kasus, memberikan klarifikasi, menunjukkan latar belakang atau alasan, mengajukan asumsi atau dugaan, memberitakan, menyindir, menambah informasi. Kedua, fungsi direktif metafora dalam wacana surat pembaca memiliki subfungsi, yaitu memohon klarifikasi, memohon pertolongan, menunjukkan tantangan, memberikan saran, mengadukan, mempertanyakan, menunjukkan tuntutan, memberikan anjuran, memotivasi, memberikan peringatan, menenangkan atau melerai, mengajak berpikir atau melakukan sesuatu, mengajukan masalah, memberikan nasehat, mengecilkan hati, mengajukan 
penolakan, mengajukan pandangan, memohonkan doa, menegaskan, menunjukkan ketidakadilan. Ketiga, fungsi ekspresif mengacu pada maksud penutur yang menunjukkan keadaan emosi atau sikap mental penggunanya. Fungsi ekspresif metafora dalam wacana surat pembaca di surat kabar harian berbahasa Indonesia mencakup empat belas subfungsi, yaitu: keterperanjatan, kepedulian, kekhawatiran, keputusasaan, harapan, kekecewaan, kekesalan, kerisauan, keprihatinan, keluhan, kemarahan, keraguan, kesangsian, dan kepasrahan.

\section{Fungsi Asertif}

Fungsi asertif metafora dapat diidentifikasi dari proposisi tuturan pada konteks ungkapan metaforis itu digunakan. Proposisi tuturan diinferensikan dari ungkapan metaforis yang digunakan penulis surat pembaca. Tuturan yang dimaksud yaitu tuturan yang mengindikasikan bahwa penutur (penulis surat pembaca) mengajukan suatu fakta atas keberadaan atau ketiadaan sesuatu. Suatu fakta yang diajukan direpresentasikan oleh tuturan yang dapat dikategorikan menurut modusnya apakah deklaratif atau tanya.

Misalnya, ungkapan (1) "bisakah hukum diperdagangkan?' Ungkapan metaforis dapat dikategorikan mengandung fungsi asertif yang mempertanyakan keberadaan hukum diperdagangkan. Secara spesifik ungkapan (1) digunakan untuk mengejek karena fungsi mengejek mengindikasikan fakta bahwa yang dilakukan interlokutor merupakan hal yang menyimpang dari nilai kebenaran seperti yang terdapat dalam bagian wacana (1) "bisakah hukum diperdagangkan? Fenomena Anggodo membuktikan bahwa ternyata hukum bisa diperjualbelikan atau diperdagangkan (komodifikasi) secara vulgar. Ungkapan (1) dapat dijadikan dasar dalam memformulasikan metafora +HUKUM ADALAH KOMODITI+. Metafora itu mengindikasikan konseptualisasi bahwa hukum dapat diperjualbelikan, yang seharusnya tidak mungkin terjadi. Hukum tidak mungkin diperdagangkan. Apabila hukum diperdagangkan, keadilan tidak dapat ditegakkan, putusan keadilan dapat dibeli atau diperjualbelikan sama seperti barang dagangan.

Ada kemiripan antara fungsi mengejek dengan fungsi mencela karena keduanya mengandung fakta negatif. Akan tetapi, perbedaan keduanya terletak pada nilai yang menjadi tolok ukur. Fungsi mengejek ditujukan pada tindakan yang menyimpang dari nilai kebenaran, sedangkan fungsi mencela ditujukan pada tindakan yang menyimpang dari nilai kebaikan. Ungkapan metaforis yang mengandung celaan adalah ungkapan yang menunjukkan fakta bahwa yang dilakukan interlokutor merupakan hal yang buruk karena menyimpang dari nilai keadilan.

Ungkapan (2) "privatisasi lembaga pendidikan semakin menggerogoti lembaga pendidikan Indonesia itu sendiri" mengindikasikan tindakan yang tidak baik atau buruk karena tindakan privatisasi menjadikan masyarakat yang lemah secara finansial tidak mampu mengikuti program pendidikan. Pendidikan adalah hak setiap warga negara seperti yang termaktub dalam Undang-Undang Dasar 1945 pasal 33. Ungkapan (2) itu menjadi dasar dalam memformulasikan metafora +PRIVATISASI LEMBAGA PENDIDIKAN ADALAH RAYAP+. Metafora itu mengandung konseptualisasi bahwa privatisasi sama dengan rayap yang mengakibatkan kayu atau bangunan yang terbuat dari kayu menjadi lapuk. Oleh karena lapuk, kayu tidak bisa berfungsi dengan baik. Kata 'menggerogoti' dapat dikategorikan metaforis karena kata itu disandingkan dengan ungkapan 'privatisasi lembaga pendidikan'. Akan tetapi, apabila kata 'menggerogoti' disandingkan dengan kata 'bangunan tua itu', kata 'menggerogoti' menjadi tidak metaforis. Ungkapan (2) menunjukkan adanya prak- 
tek yang menyimpang nilai keadilan karena pendidikan hanya untuk kelompok tertentu, yaitu kelompok orang kaya.

Subfungsi mengecam digunakan untuk menunjukkan maksud bahwa interlokutor melakukan sesuatu yang tidak boleh dilakukan, karena tindakan itu dapat membahayakan kehidupan. Kecaman disampaikan penulis surat pembaca karena adanya perbuatan manusia yang dapat membahayakan kelestarian lingkungan dan dapat mengakibatkan berbagai bencana alam, yaitu: pembalakan liar dan pembuangan sampah di sembarang tempat. Ungkapan (3) "hutan digunduli" dan (4) "sungai dijejali sampah" mengindikasikan adanya metafora (+HUTAN ADALAH KEPALA BOTAK+) dan (+SUNGAI ADALAH MULUT+). Kata 'digunduli' mengindikasikan konsep 'kepala' karena yang biasa digunduli adalah kepala. Apabila kata 'gundul' atau 'digunduli' disandingkan dengan kata 'kepala', kata itu menjadi tidak metaforis atau tidak menunjukkan adanya proses konseptualisasi, yaitu pemindahan konsep kepala ke konsep yang lain, hutan. Ketika kata 'digunduli' disandingkan dengan kata 'hutan', konstruksi gramatikal 'hutan digunduli' mengindikasikan adanya proses konseptualisasi dengan membandingkan atau membayangkan peristiwa penggundulan kepala dengan peristiwa penggundulan hutan. Keadaan gundul yang ada di kepala sama dengan keadaan gundul yang terjadi pada hutan. Perpindahan pemahaman ini menjadikan ungkapan (3) di atas metaforis.

Ungkapan metaforis yang mengandung maksud memberikan solusi atas masalah yang dihadapi masyarakat dapat dilihat dalam ungkapan (4) "Romantisme pesan yang ditaburkan seakan dirasakan sebagai obat lelahnya jiwa". Ungkapan (4) dapat menjadi dasar metafora $+\mathrm{RO}$ MANTISME PESAN ADALAH BUNGA+ yang mengindikasikan adanya fungsi memberikan solusi berkaitan dengan slogan yang tepat dalam berkampanye. Ungkapan (4) mengindikasikan adanya solusi bahwa pesan-pesan yang disampaikan dalam berkampanye hendaknya pesan-pesan yang menyejukkan hati yang dapat menimbulkan simpati pada calon yang dipilih.

Berdasarkan fungsi asertif yang dijelaskan di atas, dapat disimpulkan bahwa penulis surat pembaca selain menyampaikan hal-hal negatif yang terjadi yang mungkin merugikan masyarakat, mereka juga memberikan solusi yang dapat memberikan jalan keluar.

\section{Fungsi Direktif}

Fungsi direktif mengandung proposisi yang menunjukkan bahwa ungkapan metaforis yang digunakan penulis surat pembaca menuntut interlokutor untuk melakukan sesuatu sesuai dengan yang dikehendaki penulis surat pembaca. Akan tetapi, berhubung wacana surat pembaca adalah wacana tulis, kehadiran interlokutor tidak dapat disaksikan secara langsung. Selanjutnya, dalam menganalisis fungsi ini, diinferensikan maksud penulis surat pembaca berdasarkan konteksnya. Berikut beberapa contoh subfungsi direktif yang terkandung dalam ungkapan metaforis.

Ungkapan yang digunakan untuk menunjukkan tantangan mengindikasikan adanya tuntutan yang harus dilakukan oleh interlokutor atas tantangan yang diberikan. Tantangan yang diberikan berkaitan dengan pemberantasan korupsi yang dilakukan oleh KPK. Dari berbagai peristiwa yang diamati, penulis surat pembaca meragukan keberhasilan pemberantasan korupsi di Indonesia. Tantangan mengindikasikan sulitnya memberantas korupsi, seperti tampak pada bagian wacana (5).

(5) KPK. Hancur atau Dihancurkan? ... Mampukah bangsa ini teguh dalam memberantas korupsi dengan KPK-nya? Sanggupkah wacana pemberantasan 
korupsi direalisasi dalam politik praktis? Atau, justru sebaliknya, KPK hancur dan dihancurkan! (Wisnu Widjaja/ Jl Sindoro I No. 16 Kalibuntu Panggung, Tegal/ Republika/ Kamis 13 Agustus 2009/ Hal 4 / Kol 2).

Ungkapan 'memberantas korupsi' dan 'pemberantasan korupsi' ditempatkan dalam kalimat tanya menjadikan kedua ungkapan itu bagian dari tantangan yang diberikan. Tantangan untuk memberantas korupsi disampaikan kepada para penegak hukum, yang kredibilitasnya semakin menurun.

Ungkapan metaforis yang digunakan dalam wacana surat pembaca juga memiliki fungsi untuk mengadukan kerugian yang dialami berkaitan dengan layanan publik, seperti PDAM, listrik, pulsa. Dari ungkapan yang digunakan, dapat diinferensikan bahwa penulis surat pembaca dalam menyampaikan aduannya menuntut pihak yang terkait menindaklanjuti apa yang diadukan. Perhatikan contoh (6) berikut.

(6) METERAN BARU PDAM SEMARANG MENJERAT KONSUMEN. Sebagai warga negara dan konsumen yang baik, saya selalu melaksanakan kewajiban membayar tagihan air PDAM Semarang tepat waktu, tidak pernah terlambat apalagi menunggak, karena, memang akurasi meter air dibanding dengan pemakaian air yang keluar masih tepat, sehingga jumlah rata-rata pembayaran rekening air kami hanya berkisar Rp 70.000/ bulan, dengan jumlah pemakaian kubik air per bulan rata-rata $20-25$ meter kubik. Tapi setelah dilakukan penggantian meter air yang baru oleh PDAM semarang, tepatnya 14 Februari 2009, pemakaian air menjadi melonjak. ... tagihan air jadi melonjak, ... (Safrudin Sarif P / Jl Taman Sri Rejeki Selatan VII/32 semarang / SM/ Minggu 3 Januari 2010 / hal 7/ Kol 1)(85)

Ungkapan "Tapi setelah dilakukan penggantian meter air yang baru oleh PDAM Semarang, tepatnya 14 Februari 2009 pemakaian air menjadi melonjak. ... tagihan air jadi melonjak", mengandung aduan berkenaan dengan kenaikan yang mengagetkan setelah ada penggantian meteran oleh PDAM. Ungkapan 'tagihan air jadi melonjak' menjadi dasar dalam memformulasikan metafora +TAGIHAN ADALAH MAKHLUK BERKAKI+. Ungkapan itu berada dalam konteks linguistik "Tapi setelah dilakukan penggantian meter air yang baru oleh PDAM Semarang, tepatnya 14 Februari 2009 pemakaian air menjadi melonjak". Konteks itu yang menentukan fungsi pragmatik mengadukan.

\section{Fungsi Ekspresif}

Fungsi ekspresif digunakan oleh penulis surat pembaca untuk menunjukkan keadaan mental atau sikap atas peristiwa atau kejadian yang dialami atau yang terjadi di sekitarnya. Ungkapan metaforis yang digunakan untuk menunjukkan kepedulian mengindikasikan perasaan sedih atas bahaya yang mungkin terjadi di masa depan dapat dikenali dari ungkapan (7) "sekulerisme telah berhasil menggiring para remaja untuk menjerumuskan diri pada kehidupan yang liberal, bebas tanpa batas". Dari ungkapan (7) dapat diinferensikan bahwa penulis surat pembaca menunjukkan kepeduliannya terhadap kehidupan remaja di masa yang akan datang akan semakin rusak karena nilai-nilai moral dan sosial yang semakin dilanggar. Ungkapan (7) menjadi dasar metafora (+SEKULERISME ADALAH PENGGEMBALA+) karena yang biasa menggiring adalah penggembala yang menggiring binatang gembalaannya. Ada proses konseptualisasi bagaimana menggiring itu terjadi, tidak ada binatang gembalaan yang tidak mengikuti perintah penggembalanya, mereka dipaksa untuk mengikuti arah yang ditujukan penggembala. Ungkapan (7) mengindikasikan 
adanya fakta yang dikhawatirkan akan terjadi setelah melihat fenomena yang menunjukkan kehidupan remaja yang cenderung tidak baik.

Ungkapan metaforis yang digunakan untuk menunjukkan harapan mengindikasikan suatu angan-angan tentang suatu hal yang baik atau lebih baik di masa yang akan datang, atau suatu tindakan yang dilakukan yang dapat membuat sesuatu menjadi lebih baik. Ungkapan (8) "Saya hanya bisa berharap, ke depan Purwokerto dapat tumbuh menjadi kota yang lebih ramah bagi kehidupan para warganya", mengandung fungsi ekspresif 'menunjukkan harapan' yang diungkapkan secara eksplisit dengan menyatakan 'Saya hanya bisa berharap', sebagai indikator keeksplisitan tindak ilokusi itu. Ungkapan 'Purwokerto dapat tumbuh' menjadi kota yang 'lebih ramah' menjadi dasar memformulasikan metafora +PURWOKERTO/KOTA ADALAH MANUSIA+. Kata 'ramah' mengindikasikan adanya konsep manusia karena yang biasanya memiliki ciri ramah adalah manusia.

Ungkapan yang digunakan untuk menunjukkan kekecewaan adalah ungkapan yang mengindikasikan perasaan kecewa atas suatu hal yang seharusnya tidak terjadi atau tidak dilakukan, tetapi terjadi atau dilakukan. Ungkapan (9) "KPK Hancur atau Dihancurkan" menjadi dasar dalam memformulasikan metafora +KPK ADALAH BANGUNAN+. Metafora itu mengandung konseptualisasi bahwa KPK adalah bangunan, yang secara visual dapat dibuktikan bagaimana suatu bangunan berdiri. Ungkapan (9) mengindikasikan kekecewaan atas tidak adanya harapan yang lebih baik terjadi berkaitan dengan pemberantasan korupsi. Kekecewaan muncul karena kepercayaan yang hilang.

Ungkapan metaforis yang digunakan untuk menunjukkan kekesalan adalah ungkapan yang mengandung apa atau tindakan apa yang membuat lokutor tidak suka. Ketidaksukaan itu dikarenakan kejadian atau tindakan yang dilakukan atau sesuatu yang terjadi itu sesuatu yang tidak diinginkan atau suatu tindakan yang seharusnya tidak dilakukan tetapi tetap dilakukan. Ungkapan (10) "Sistemnya sudah bobrok, yang dibobrok-bobrokkan oleh oknum. Jadi lembaganya sudah bobrok..." mengindikasikan adanya kekesalan dalam diri lokutor mengenai KPK. Ungkapan (10) menjadi dasar dalam memformulasikan metafora +SISTEM ADALAH MOBIL YANG RUSAK+. Metafora itu mengandung konseptualisasi yang menggambarkan sistem adalah mobil yang rusak. Oleh karena rusak tentunya, apapun tidak bisa berfungsi dengan baik.

Ungkapan metaforis yang digunakan untuk menunjukkan kerisauan adalah ungkapan metaforis yang mengindikasikan perasaan galau atau risau karena adanya hal buruk yang akan terjadi. Pengaruh budaya asing yang sangat kuat menjadikan rasa nasionalisme para pemuda dan anak muda menjadi hilang atau sirna. Ungkapan (11) "gempuran budaya asing" mengindikasikan betapa kuat pengaruh budaya asing terhadap kehidupan para pemuda sehingga dapat menjadikan mereka melupakan rasa nasionalisme.

Ungkapan metaforis yang digunakan untuk menunjukkan keprihatinan adalah ungkapan yang mengindikasikan adanya suatu hal yang merusak terjadi, yang berkaitan dengan media yang sarat aksi merangsang naluri seksual seperti bacaan, gambar-bambar, VCD hingga situs berbau pornoaksi dan pornografi. Ungkapan (12) "kehidupan remaja dibombardir oleh media" mengindikasikan adanya keprihatinan yang disampaikan karena pengaruh media yang memaparkan aksi merangsang naluri seksual yang akan merusak mental generasi muda.

Ungkapan metaforis yang menunjukkan keluhan adalah ungkapan yang 
mengindikasikan adanya peristiwa yang merugikan terjadi pada penulis surat pembaca. Keluhan diungkapkan ketika penulis surat pembaca mendapati jatah kuota internet dikurangi dan penonaktifan koneksi internet.

Ungkapan metaforis yang digunakan untuk menunjukkan kesangsian mengindikasikan adanya keraguan atas suatu hal yang baik tetap dipertahankan karena adanya sikap negatif terhadap hal yang baik itu. Ungkapan metaforis (13) "kebaya tidak mempunyai tempat lagi di hati mereka" mengindikasikan bahwa mereka (remaja) memiliki sikap negatif terhadap kebaya karena beberapa alasan, salah satunya tidak modis.

Ungkapan metaforis yang digunakan untuk menunjukkan kepasrahan adalah ungkapan yang mengindikasikan adanya pembiaran sesuatu terlanjur terjadi. Data (14) "Biaya, tenaga, pikiran, dan waktu sudah saya curahkan" mengindikasikan adanya pembiaran bahwa lokutor telah mencurahkan semua biaya, tenaga, pikiran, dan waktu kepada interlokutor tetapi perbuatan baik yang lokutor berikan justru dibalas dengan perbuatan yang menipu. Pembiaran terhadap balasan yang tidak setimpal dengan tindakan baik yang dilakukan menunjukkan kepasrahan yang dimiliki lokutor.

\section{Strategi Kesantunan}

Tuturan dalam wacana surat pembaca dapat dikategorikan mengandung tindakan mengancam muka. Hal itu dikarenakan tuturan yang disampaikan dalam wacana surat pembaca dimungkinkan mengganggu hubungan antara penulis surat pembaca dengan seseorang atau lembaga yang menjadi sasaran komunikasinya. Goffman menyebutkan bahwa strategi kesantunan digunakan untuk menjaga 'muka' orang lain (Renkema, 2004:25). Strategi kesantunan yang digunakan oleh penulis surat pembaca merupakan strategi kesantunan yang secara simultan dapat dikategorikan menjadi strategi langsung atau terus terang dan tidak langsung atau samar-samar. Gazdar menyebutkan bahwa kelangsungan dan ketidaklangsungan dapat dikenali menurut hipotesis daya literal ( $L F H=$ Literal Force Hypothesis) (Levinson, 983:263-264). Dalam konteks ini ada dua hal yang perlu dicermati. Pertama, keberadaan verba performatif yang digunakan dalam klausa yang memenuhi syarat mengandung tindak tutur performatif yang terkandung dalam verba itu. Kedua, kesesuaian antara tiga jenis kalimat dengan daya yang secara tradisional dilekatkan pada ketiga jenis kalimat itu. Misalnya, kalimat tanya untuk bertanya. Akan tetapi, strategi kesantunan yang digunakan oleh penulis surat pembaca cenderung samar-samar karena ketidaksesuaian antara modus dan maksud yang dikandungnya.

Dalam menulis surat pembaca, penulis sedang membayangkan bahwa ia melakukan interaksi dengan pembaca yang dimaksud. Ada suatu pertimbangan yang diperhatikan ketika menyusun tuturannya dalam surat pembaca agar ia dapat memperkokoh hubungannya sebagai lokutor dan pembaca sebagai interlokutor (Leech, 1983). Goffman menyatakan bahwa dalam kontak sosial setiap orang menuntut untuk dihormati oleh orang lain dan menuntut untuk tidak diganggu (Renkema, 2004:25). Yule (1996:61-62) menambahkan bahwa keinginan untuk dianggap dalam kelompok yang sama dikategorikan sebagai muka positif dan keinginan untuk dianggap dalam kelompok yang berbeda dikategorikan sebagai muka negatif. Dalam menulis surat pembaca, penulis cenderung menunjukkan keinginan untuk mengategorikan dirinya berada dalam kelompok yang berbeda dengan pembaca sebagai iterlokutornya, yaitu sebagai representatif lembaga nonpemerintah, pengguna jasa pemerintah, pengguna produk, dan warga masyarakat. 
Dengan perannya seperti yang telah disebutkan di atas, penulis surat pembaca menggunakan ungkapan-ungkapan metaforis yang dapat diformulasikan menjadi metafora-metafora yang dapat dikategorikan metafora publik (Punter, 2007). Kondisi itu menempatkan penulis surat pembaca memiliki power atau kekuasaan yang berbeda dengan pembaca sebagai interlokutornya. Sebagai contoh, sebagai konsumen produk atau jasa, penulis surat pembaca memiliki kekuasaan yang lebih tinggi dari produsen atau penyedia jasa. Kekuasaan untuk dapat menuntut produsen atau penyedia jasa memberikan kualitas yang sesuai dengan yang diinginkan konsumen. Apabila tidak terpenuhi keinginannya, konsumen memiliki alasan yang kuat untuk tidak membeli produk atau menggunakan jasa yang ditawarkan. Suatu hal yang tidak diinginkan oleh produsen akan kehilangan konsumennya.

Strategi kesantunan yang dipaparkan didasarkan pada fungsi pragmatik metafora karena strategi kesantunan berkorespondensi dengan kelangsungan tindak tutur yang terkandung dalam setiap tuturan. Indikator yang dijadikan parameter dalam menentukan kelangsungan tindak tutur adalah kesesuaian antara modus dan maksud tuturan (Levinson, 1983:263-264). Sebagai contoh, modus tanya digunakan untuk bertanya seperti dalam data (14) "Pajak larinya kemana?". Ungkapan itu digunakan penulis surat pembaca untuk bertanya kepada lembaga yang memiliki otoritas mengumpulkan pajak. Apabila dikaitkan dengan fungsi pragmatik, strategi kesantunan yang digunakan penulis surat pembaca dalam (14) dapat dikategorikan langsung. Strategi langsung digunakan untuk menyampaikan maksudnya untuk menanyakan keberadaan pajak yang dikelola.

Tindak tutur direktif mengimplikasikan fungsi pragmatik yang mengancam muka karena mengandung proposisi yang digunakan lokutor untuk menuntut interlokutor melakukan sesuatu sesuai dengan yang dikehendaki penulis surat pembaca. Dalam fungsi direktif, penulis surat pembaca memiliki kekuasaan yang lebih besar dibandingkan pembaca. Sebagai contoh, penulis surat pembaca yang mengadukan kerugian yang dialami karena layanan penyedia jasa yang tidak baik, memiliki kekuasaan yang lebih besar dibandingkan dengan interlokutornya dalam hal ini penyedia jasa. Sebagai konsumen, penulis surat pembaca dapat menciptakan kesan buruk terhadap penyedia jasa yang dapat mengakibatkan turunnya minat pengguna jasa yang sekaligus dapat menurunkan minat pasar.

Strategi kesantunan tidak langsung digunakan untuk mengadukan kerugian yang dialami penulis surat pembaca sebagai pelanggan. Ungkapan metaforis yang digunakan untuk mengadukan kerugian yang dialami berkaitan dengan layanan publik, seperti PDAM, listrik, dan pulsa. Dari ungkapan yang digunakan, dapat diinferensikan bahwa penulis surat pembaca dalam menyampaikan aduannya menuntut pihak yang terkait menindaklanjuti apa yang diadukan. Data (15) "Meteran Baru PDAM Semarang Menjerat Konsumen" yang diperjelas dengan ungkapan “Tapi setelah dilakukan penggantian meter air yang baru oleh PDAM Semarang, tepatnya 14 Februari 2009 pemakaian air menjadi melonjak", mengandung maksud mengadukan berkenaan dengan kenaikan yang mengagetkan setelah ada penggantian meteran oleh PDAM. Apabila dilihat secara sintaksis dan modus tuturannya, ungkapan di atas bermodus berita atau deklaratif. Akan tetapi, apabila dilihat dari konteksnya, dengan ungkapan metaforis itu, penulis surat pembaca tidak hanya memberitakan bahwa meteran baru PDAM menjerat konsumen dan adanya pelonjakan tagihan, tetapi ia menuntut adanya penyelesaian kerugian yang dialami oleh pengelola PDAM. 
Strategi kesantunan langsung juga digunakan penulis surat pembaca untuk menunjukkan tuntutan agar yang diupayakan interlokutor berjalan dengan baik dan berhasil, memberikan anjuran untuk melakukan sesuatu yang dapat menyelamatkan bumi, memberikan motivasi kepada interlokutor untuk tetap semangat melakukan hal yang positif, mengajukan masalah, mengecilkan hati, mengajukan penolakan, mengajukan pandangan, menegaskan, menunjukkan ketidakadilan, mengajak melakukan sesuatu seperti yang dilakukan penulis surat pembaca. Kelangsungan maksud dapat dikenali adanya penanda modalitas. Sebagai contoh, kelangsungan maksud mengajak ditunjukkan oleh penanda modalitas 'ada baiknya' dalam ungkapan "ada baiknya mengontrol dan mengerem emosi masingmasing dan menenangkan hati dalam menghadapi masalah". Strategi kesantunan langsung yang digunakan untuk menenangkan hati ditunjukkan oleh penanda modalitas 'harus' dalam data (16) “Tetapi pengurus harus tetap optimistis karena Jateng gudangnya pemain berkualitas dan potensial" yang mengindikasikan bahwa interlokutor wajib melakukan hal yang dikemukakan lokutor untuk mengatasi masalah yang dihadapi.

Selain strategi kesantunan langsung, ungkapan metaforis juga menyiratkan strategi kesantunan tidak langsung. Seperti yang dijelaskan di atas, kelangsungan strategi ditunjukkan oleh penanda-penanda linguistis antara lain adanya modalitas, dan aspek pragmatik yang ditunjukkan oleh keurgenan suatu tindakan yang harus segera dilakukan (rate of imposition) (Goffman dalam Renkema, 2004:24-26); (Scollon dan Scollon, 1995). Strategi kesantunan tidak langsung dilakukan untuk mengajukan permohonan klarifikasi atas kesalahan yang dilakukan interlokutor.

Ungkapan "ada yang perlu kami klarifikasi" mengindikasikan bahwa lokutor bermaksud untuk meminta klarifikasi dari interlokutor karena ada kekeliruan. Data (17) "mencampuradukkan PPMK dan Koperasi sangatlah keliru. Kami tidak mempermasalahkan jumlah dana yang akan dikucurkan per kelurahan..." mengandung fungsi untuk memohon klarifikasi atas permasalahan pemberian dana per kelurahan karena PPMK dan Koperasi dicampuradukkan sehingga pemberian dana tidak jelas. Secara sintaksis tuturan di atas dikategorikan mengandung strategi tidak langsung, karena tidak adanya kesesuaian antara modus tuturan yang berbentuk deklaratif dengan maksud tuturan untuk memohon klarifikasi. Akan tetapi, secara pragmatik tuturan itu mengandung strategi kesantunan tidak langsung. Apabila parameter tingkat pentingnya (rate of impossition) yang digunakan untuk menentukan strategi kesantunan yang terkandung dalam data (17) di atas, dapat diinferensikan bahwa masalah yang diajukan penulis segera diklarifikasi. Parameter lainnya yang mendukung adalah kedudukan warga masyarakat yang memiliki kontrol sosial yang tinggi atas penyelenggaraan program pemerintah. Power atau kekuasaan warga menjadi lebih tinggi dibandingkan pemerintah sebagai penyelenggara pemerintahan. Dalam mekanisme tertentu wargalah yang menentukan terpilih tidaknya seorang penyelenggara pemerintahan.

Strategi kesantunan tidak langsung juga digunakan penulis surat pembaca ketika menunjukkan tantangan dengan menggunakan modus tuturan tanya, seperti tampak pada data (18) "Mampukah bangsa ini teguh dalam memberantas korupsi dengan KPKnya?" dan "Sanggupkah wacana pemberantasan korupsi direalisasi dalam politik praktis?". Kedua tuturan yang bermodus tanya itu bukan hanya digunakan penulis surat pembaca untuk menanyakan kemampuan dan kesanggupan KPK sebagai lembaga yang memiliki otoritas tinggi dalam memberantas korupsi, tetapi mengandung maksud 
untuk menunjukkan tantangan kepada lembaga penegak hukum untuk dapat menghilangkan korupsi di Indonesia yang tercinta ini.

Strategi kesantunan tidak langsung juga digunakan untuk memberikan saran, memberikan peringatan, dan memberikan nasehat. Ketidaklangsungan ditunjukkan oleh maksud yang mengindikasikan bahwa penulis surat pembaca memberikan kebebasan kepada pembaca untuk setuju atau tidak setuju dengan yang dikemukakan penulis surat pembaca. Keputusan diserahkan sepenuhnya kepada pembaca yang menjadi interlokutor dalam komunikasi yang dilakukan.

\section{SIMPULAN}

Fungsi pragmatik metafora menunjukkan adanya keselarasan antara fungsi surat pembaca yang digunakan untuk menyampaikan keluhan, kritikan, dan gagasan tentang yang terjadi di lingkungan di mana penulis surat pembaca tinggal. Oleh karena itu, ungkapan metaforis yang digunakan penulis surat pembaca ditengarai mengandung fungsi asertif untuk menyampaikan keberadaan atau ketiadaan suatu fakta yang baik atau yang kurang atau tidak baik menurut nilainilai kemanusiaan. Selain itu, ungkapan metaforis mengandung fungsi direktif untuk menuntut interlokutor melakukan sesuatu yang diinginkan lokutor untuk memperbaiki layanan yang dikeluhkan. Fungsi ekspresif digunakan penulis surat pembaca untuk menunjukkan keadaan mental atau emosi dan sikap penulis surat pembaca terhadap semua yang disaksikan atau dialami penulis surat pembaca terutama berkaitan dengan peristiwa yang tidak mengenakkan yang berkaitan dengan hukum dan pendidikan.

Fungsi komisif yang merupakan suatu tindakan yang menunjukkan komitmen penulis surat pembaca untuk melakukan sesuatu tidak ditemukan dalam data. Hal ini dimungkinkan karena fungsi surat pembaca yang utama adalah untuk mendapatkan adanya upaya perbaikan dari interlokutor. Selain itu, fungsi deklarasi (declarations) yang menunjukkan adanya perubahan keadaan setelah diungkapkannya ungkapan itu juga tidak ditemukan dalam data. Sesuai dengan fungsinya, surat pembaca ditulis bukan untuk mengubah suatu status yang dapat mengubah keadaan, karena penulis surat pembaca tidak memiliki otoritas untuk melakukannya.

Strategi kesantunan yang digunakan oleh penulis surat pembaca cenderung tidak langsung. Meskipun demikian, ditemukan juga strategi langsung yang disebabkan oleh penanda-penada linguistik yang dapat dikenali.

\section{UCAPAN TERIMA KASIH}

Pada kesempatan ini penulis menyampaikan terima kasih kepada Prof. Dr. I Dewa Putu Wijana, SU., MA sebagai promotor dan Prof. Stephanus Djawanai, MA., Ph.D sebagai kopromotor, yang telah memberikan bimbingan dalam penulisan disertasi yang berjudul "Metafora dalam Wacana Surat Pembaca di Surat Kabar Harian Berbahasa Indonesia" yang menjadi induk tulisan ini. Ucapan terima kasih juga disampaikan kepada reviewer ahli yang telah memberi catatan, masukan, dan pembenahan aspek kebahasaan untuk perbaikan artikel ini.

\section{DAFTAR PUSTAKA}

Austin, J.L. 1968. How to do Things with Words. New York: Oxford University Press.

Brown, Penelope dan Stephen C Levinson. 1987. Politeness. Some Universals in Language Usage. Cambridge: Cambridge University Press.

Croft, William dan D Alan Cruse. 2004. Cognitive Linguistics. Cambridge: Cambridge University PressS 4512, hal 97-111. Springer-Verlag Berlin Heidelberg 2007. 
Djawanai, Stephanus. 2009. 'Telaah Bahasa, Telaah Manusia'. Pidato Pengukuhan Jabatan Guru besar dalam Ilmu Linguistik pada Fakultas Ilmu Budaya Universitas Gadjah Mada, tidak diterbitkan. Fakultas Ilmu Budaya UGM Yogyakarta

Evans, Vyvyan dan Melanie Green. 2006. Cognitive Linguistics: An Introduction. Edinburgh: Edinburgh University Press.

Kittay, Eva Feder. 1987. Metaphor: Its Cognitive Force and Linguistic Structure. Oxford: Clarendon Press

Krippendorff, Klaus. 2004. Content Analysis:An Introduction to Its Methodology. California: Sage Publications, Inc.

Lakoff, George dan Johnson, Mark. 2003. Metaphors We Live By. Chicago dan London: The University of Chicago Press.

Langacker, Ronald W. 1987. Foundations of Cognitive Grammar. Vol 1, Theoretical Prerequisites. Stanford: Stanford university Press.

Leech, Geoffrey N. 1983. Principles of Pragmatics.London: Longman

Levinson, Stephen C. 1983. Pragmatics. Cambridge: Cambridge University Press

Murdowo, Drajat Agus. 2006. 'Kemetaforaan Puisi-puisi Karya M. Fadjroel Rahman Sebuah Kritik Sosial'. Laporan Penelitian Tidak Diterbitkan. Balai Bahasa Semarang Pusat Bahasa Departemen Pendidikan Nasional.

Oktavianus. 2005. 'Kias dalam Bahasa Minangkabau'. Disertasi Tidak Diterbitkan. Pogram Doktor Program Studi Linguistik Program Pascasarjana Universitas Udayana Denpasar.

Punter, David. 2007. Metaphor. New York: Routledge
Renkema, Jan. 2004. Introduction to Discourse Studies. Amsterdam: John Benjamins Publishing Company

Ruiz, Javier Herrero. 2006. “The Role of Metaphor, Metonymy, and Conceptual Blending in Understanding Advertisements: The Case of Drug-prevention Ads". Revista Alicantina de Estudios Ingleses Vol 19, pp. 160-190

Searle, John R. 1977. Speech Acts. Cambridge: Cambridge University Press.

Scollon, Ron dan Scollon, Suzanne Wong. 1995. Intercultural Communication. A Discourse Approach. Oxford: Blackwell.

Siregar, Bahren Umar. 2004. "Metafora Kekuasaan dan Metafora melalui Kekuasaan: Melacak Perubahan Kemasyarakatan melaui Perilaku Bahasa". PELBBA 17. Jakarta: Yayasan Obor Indonesia. Hal 139-189

Sperber, Dan dan Deirdre Wilson. 1995. Relevance: Communication and Cognition. Second Edition. Oxford: Blackwell Publishers, Ltd.

Stern, Josef. 2000. Metaphor in Context. Cambridge: The MIT Press

Sudaryanto. 1993. Metode dan Aneka Teknik Analisis Bahasa. Pengantar Penelitian Wahana Kebudayaan secara Linguistis. Yogyakarta: Duta Wacana University Press

Vanderveken, Daniel. 1990. Meaning and Speech Acts. Volume II. Formal Semantics of Success and Satisfaction. Cambridge: Cambridge University Press

Wahab, Abdul. 1986. Javanese Metaphors in Discourse Analysis. Disertasi tidak diterbitkan. Program Pascasarjana Universitas Illinois, Urbana-Champain.

Yule, George. 1996. Pragmatics. Oxford: Oxford University Press 